\title{
HYGIENIC-SANITARY CONDITIONS OF VEGETABLES AND IRRIGATION WATER FROM KITCHEN GARDENS IN THE MUNICIPALITY OF CAMPINAS, SP
}

\author{
Marise Simões $^{1 *}$; Beatriz Pisani ${ }^{1}$; Eneida Gonçalves Lemes Marques ${ }^{1}$; Maria Angela Garnica Prandi ${ }^{1}$; \\ Maria Helena Martini ${ }^{1}$; Paulo Flávio Teixeira Chiarini ${ }^{1}$; José Leopoldo Ferreira Antunes ${ }^{2}$ Ana Paula Nogueira ${ }^{3}$ \\ ${ }^{1}$ Instituto Adolfo Lutz, Laboratório Regional de Campinas, SP, Brasil; ${ }^{2}$ Universidade de São Paulo, Faculdade de Odontologia, \\ São Paulo, SP, Brasil; ${ }^{3}$ Secretaria Municipal de Saúde de Campinas, Campinas, SP, Brasil.
}

Submitted: July 19, 2000; Returned to authors for corrections: March 12, 2001; Approved: November 21, 2001

\section{SHORT COMMUNICATION}

\begin{abstract}
We examined samples of irrigation water and vegetables from kitchen gardens in Campinas, Brazil. The bacterial analysis condemned $22.3 \%$ of the vegetable samples, and the parasitological examination condemned $14.5 \%$. The criteria established by the Brazilian legislation condemned $11.8 \%$ of the irrigation water samples. Parasites were significantly more frequent in vegetables in the rainy season, while excessive fecal coliforms were more frequent in the dry season. A proper monitoring of the irrigation water supply is important to avoid the contamination of vegetables.
\end{abstract}

Key words: vegetables, irrigation water, bacteria, parasites.

In Brazil, the widespread habit of consuming raw vegetables allows for the transmission of diseases caused by bacteria, parasites and viruses. Vegetables are cultivated throughout the year, sometimes in soil beds fertilized with animal manure. Plant roots are in constant contact with the soil and often irrigated with polluted water. Studies have demonstrated that pathogens present in contaminated soil may remain viable for up to 2 months or more, especially in moist and shaded areas. Since vegetables require a moist environment for their growth, these conditions favor the development of transmissible forms of enteroparasites such as protozoan cysts, helminthes eggs, and viruses $(12,13,18)$.

The protozoan Cryptosporidium parvum has been recognized since 1980 as a common cause of gastroenteritis, mainly in children and immunodepressed adults, and can cause profuse diarrhea with a great loss of body fluids (19). However, although C. parvum transmission may occur via water or food intake (11), the role of this type of transmission is poorly documented.

Many outbreaks have been associated with the consumption of fresh vegetables contaminated with Salmonella sp, Escherichia coli O157:H7, Shigella sp, Aeromonas sp, Listeria monocytogenes and Bacillus cereus. These contaminations proceed from the soil, water, pre- and post-harvest handling, etc. (2). In spite of their importance as a public health problem, there are few reports on intestinal parasites and food-borne diseases in the Brazilian bio-medical literature $(12,13)$. Thus the present study aimed at the evaluation of the hygienic-sanitary conditions of vegetable and irrigation water samples in a large Brazilian city, by detecting microorganisms indicative of fecal contamination.

One hundred and sixty six vegetable samples: 62 lettuce (Lactuca sativa), 39 wild chicory (Chichorium sp), 26 chicory (Chichorium endivia), 14 arugula (Eruca sativa), and 25 parsley (Petroselinum sativum) were examined. These samples were collected between July 1997 and November 1998, from 96 registered kitchen gardens in 29 regions of the city of Campinas, SP, Brazil. Ninety three samples of water used for the irrigation of these vegetables: 29 proceeding from mines, 19 from wells, 28 from the public water system, 13 from ponds and 4 from brook were also examined. Some kitchen gardens used the same source of water. Technicians from the Municipal Sanitary Vigilance Service collected one water sample and two samples of each type of vegetable from each kitchen garden.

The irrigation water samples were analysed according to the membrane filter method described by the American Public Health Association - APHA (5). Samples were classified as

\footnotetext{
* Corresponding author. Mailing address: Instituto Adolfo Lute - Laboratório Regional de Campinas - Rua São Carlos, 720 - Vila Industrial - 13035-420, Campinas, SP, Brasil, Fax: (+5519) 3273-1698. E-mail: msimoes55@ hotmail.com
} 
condemned or non-condemned based on the Brazilian governmental regulation (16), which establishes a limit of 1000 colony-forming units (CFU) of coliforms per $100 \mathrm{ml}$.

Each vegetable sample was collected in duplicate for the bacteriological and parasitological analyses. After labelling the samples were transported to the laboratory in sterile plastic bags. The bacteriological analysis of the vegetables followed the APHA methods for fecal coliforms and Salmonella sp $(6,7)$. The results were interpreted according to the governmental regulations (3), which stipulate the limit for fecal coliforms (200 CFU/g), and the absence of Salmonella sp in $25 \mathrm{~g}$ of product.

The centrifugal-flotation technique $(12,13)$ was used to detect the presence of the eggs and larvae of helminthes and protozoan cysts in the examination of the vegetable samples. To detect $C$. parvum, a sample of approximately $2 \mathrm{ml}$ of the sediment obtained after the sedimentation phase, was mixed with $4 \mathrm{ml}$ of $10 \%$ Formalin. This material was submitted to the modified technique for concentration using formol-ether, followed by staining using the modified Ziehl-Neelsen technique (1). The results were interpreted according to the governmental regulations which stipulate the absence of parasites and larvae in the sample (17). Samples were only condemned however, it they presented parasite cysts, eggs or larvae which were pathogenic to humans. It was considered that nematode larvae are commonly found in the soil, existing in the free-life form, and do not necessarily indicate fecal contamination.

The bacterial examination of the vegetables condemned 37 (22.3\%) samples; 33 (19.9\%) presented fecal coliforms above $200 \mathrm{CFU} / \mathrm{g}$ and $4(2.4 \%)$ were Salmonella sp positive. In addition, 24 (14.5\%) presented parasites (Table 1). The statistical analysis indicated that the frequency of sample condemnation due to an excess of fecal coliforms was not significantly different from that due to the presence of parasites ( $>>0.05)$. Although 51 water samples presented fecal coliforms, only 11 exceeded the limit established, and were thus condemned.

Arugula presented a significantly higher frequency of parasites $(35.7 \%, \mathrm{p}<0.05)$. Parsley presented the lowest level of microbial and parasitic contamination, although not significantly different from the other vegetables ( $p>0.05)$. However, one sample of parsley was Salmonella sp positive, being unsuitable for human consumption (Table 2). Table 2 also quantifies the presence of parasites in vegetables. All samples were negative for C. parvum. During the rainy season (December to April), the frequency of contamination of the vegetables by parasites $(28.0 \%)$ was significantly higher $(\mathrm{p}<0.05)$ than in the dry season (May to November - 95.0\%). On the other hand, the condemnation of samples due to fecal coliforms was significantly higher $(\mathrm{p}<0.05)$ in the months of low rainfall $(74.1 \%)$ as compared to the rainy season $(56.0 \%)$.

Although the bacterial analysis did not indicate an association between the vegetables and the irrigation water samples ( $p>0.05$ ), further studies with a wider range of samples should test the effectiveness of the water used for irrigation as a vehicle for the contamination of vegetables. Other factors should also be considered: the use of organic fertilizer (animal manure), the rearing of animals in nearby areas, and the presence of cesspits close to the cultivation area (15).

The presence of trichomes on the surface of arugula leaves and their irregularity, which facilitate the adhesion of eggs and larvae, may have contributed to the high frequency of parasites $(4,14)$. The dense and smooth cuticle of parsley contributes to prevent the presence of parasites. Methods commonly used for the detection of oocysts of $C$. parvum are limited, and frequently fail (19). There are no appropriate techniques for the detection of $C$. parvum in foods and therefore an adaptation of clinical methods was necessary $(8,11)$. In this study, the effectiveness of a combination of methodologies listed in the Brazilian literature, in which a method for the detection of parasites in vegetables $(12,13)$ was associated with a method for searching for C. parvum in stool samples was evaluated (1). However, this procedure only gave negative results.

All Entamoeba sp cysts detected in the samples presented four nuclei. Although being a characteristic of $E$. histolytica, these cysts could not be morphologically distinguished from the cysts of E. moshkovskii, a free-living amoeboid (11). In addition, the detection of many free-living nematode larvae was not registered, since they could not be identified.

The observation of seasonal variations in the detection of fecal coliforms and parasites in vegetables is well known. Oliveira and Germano (12) stated that helminth eggs might remain viable for longer periods in moist environments in dry ones. Marzochi $(9,10)$ also reported that water is an important factor in the spread of diseases caused by enteroparasites. Water does not interfere with the viability of eggs, allowing for the survival of the resistant forms (cysts) of parasitic protozoans. These observations are consistent with the results of the present study, in which rain was associated with the survival of parasites in vegetables.

During the dry season, the more intense irrigation of kitchen gardens contributes to the higher frequency of fecal coliforms

Table 1. Frequency of irrigation water and vegetable samples condemned according to the source of water.

\begin{tabular}{|c|c|c|c|c|c|c|c|c|}
\hline \multirow{3}{*}{$\begin{array}{c}\text { Source of } \\
\text { water }\end{array}$} & \multirow{2}{*}{\multicolumn{2}{|c|}{$\begin{array}{c}\text { Condemned } \\
\text { Irrigation } \\
\text { Waters }\end{array}$}} & \multicolumn{6}{|c|}{ Condemned Vegetables } \\
\hline & & & \multicolumn{2}{|c|}{$\begin{array}{c}\text { Fecal } \\
\text { coliforms }\end{array}$} & \multicolumn{2}{|c|}{$\begin{array}{c}\text { Salmonella } \\
\mathrm{sp}\end{array}$} & \multicolumn{2}{|c|}{ Parasite } \\
\hline & $\mathrm{N}$ & $\%$ & $\mathrm{~N}$ & $\%$ & $\mathrm{~N}$ & $\%$ & $\mathrm{~N}$ & $\%$ \\
\hline & 01 & 7.7 & 03 & 16.7 & 0 & & 01 & \\
\hline & & & 11 & 21 & 03 & 8 & 10 & .9 \\
\hline & & & 08 & 26.7 & 0 & 0 & 04 & $13 .$. \\
\hline & & & & 0.0 & 01 & 12.5 & 04 & 50. \\
\hline & & & & 19 & & 00 & 05 & 8.9 \\
\hline Total (93) & 11 & 11.8 & 33 & 19.9 & 04 & 2.4 & 24 & 14.5 \\
\hline
\end{tabular}


Table 2. Occurrence of microorganisms and parasites in vegetables.

\begin{tabular}{|c|c|c|c|c|c|c|c|c|c|c|}
\hline \multirow[t]{2}{*}{ Microorganisms } & \multicolumn{2}{|c|}{ Lettuce (62) } & \multicolumn{2}{|c|}{ Wild chicory (39) } & \multicolumn{2}{|c|}{$\begin{array}{c}\text { Vegetables } \\
\text { Chicory (26) }\end{array}$} & \multicolumn{2}{|c|}{ Arugula (14) } & \multicolumn{2}{|c|}{ Parsley (25) } \\
\hline & $\mathrm{N}$ & $\%$ & $\mathrm{~N}$ & $\%$ & $\mathrm{~N}$ & $\%$ & $\mathrm{~N}$ & $\%$ & $\mathrm{~N}$ & $\%$ \\
\hline Salmonella $\mathrm{sp}$ & 1 & 1.6 & 2 & 5.1 & 0 & 0.0 & 0 & 0.0 & 1 & 4.0 \\
\hline Fecal coliforms & 12 & 19.3 & 8 & 21.0 & 6 & 23.1 & 5 & 35.7 & 2 & 8.0 \\
\hline Ancilostomidae & 4 & 6.4 & 4 & 10.2 & 2 & 7.7 & 4 & 28.6 & 1 & 4.0 \\
\hline S. stercoralis & 0 & 0.0 & 2 & 5.1 & 2 & 7.7 & 1 & 7.1 & 0 & 0.0 \\
\hline Tricostrongilidae & 0 & 0.0 & 0 & 0.0 & 1 & 3.8 & 0 & 0.0 & 0 & 0.0 \\
\hline Entamoeba sp & 2 & 3.2 & 0 & 0.0 & 1 & 3.8 & 0 & 0.0 & 0 & 0.0 \\
\hline
\end{tabular}

in vegetables. Although only $11.8 \%$ of the water samples were considered inadequate for human consumption, $54.8 \%$ presented coliforms. Therefore, the microbiological criteria for the condemnation of irrigation water samples should be reevaluated. The sanitary control of vegetables must also consider the presence of cesspits and the rearing of animals in the vicinity of kitchen gardens. Educational programs should alert producers how to improve the cultivation and harvesting of vegetables, and how to monitor the quality of the water used for irrigation.

We also suggest the revision of the legislative criteria regarding the results of parasitological analyses, which should establish specific parameters for the identification of larvae in vegetables. Although $C$. parvum was not detected in the vegetable samples, its presence should not be disregarded. As the importance of this microorganism in the etiology of gastroenteritis should not be underrated, new laboratory techniques aiming at its detection must be developed.

\section{RESUMO}

\section{Condições higiênico-sanitárias das hortaliças e águas de irrigação de hortas no município de Campinas, SP}

Foram analisadas amostras de água de irrigação e vegetais de hortas de Campinas, SP. A análise bacteriana condenou 22,3\% das hortaliças e o exame parasitológico condenou $14,5 \%$. O critério estabelecido pela legislação brasileira condenou $11,8 \%$ das amostras de água de irrigação. A contaminação de hortaliças por parasitas foi significantemente mais freqüente na estação chuvosa, enquanto o excesso de coliformes fecais foi mais frequiente na estação seca. $\mathrm{O}$ monitoramento adequado da água de irrigação é importante para evitar a contaminação de vegetais.

Palavras-chave: hortaliças, águas de irrigação, bactérias, parasitas .

\section{REFERENCES}

1. Baraldi, S.R.; Marques, E.G.L.; Dias, R.M.D.S. Ocorrência de Cryptosporidium parvum e Isospora belli na região de Campinas, SP. Rev. Inst. Adolfo Lutz, 58(1): 97-103, 1999.
2. Beauchat, L.R. Pathogenic microorganisms associated with fish produce. J. Food Prot., 59(2): 204-216, 1996.

3. Brasil. Leis, Decretos, etc. Portaria $\mathrm{n}^{\circ} 451$ de 19 de setembro de 1997. SVS/ Ministério da Saúde, Diário Oficial, Brasília, 2 de julho de 1998, seção 1, 124E, p.4-13.

4. Christovão, D.A.; Iaria, S.T.; Candeias, J.A.N. Condições sanitárias das águas de irrigação de hortas do município de São Paulo. I Determinação da intensidade de poluição fecal através NMP de coliformes e de E. Coli. Rev. Saúde Públ., 1(1): 3-11, 1967.

5. Eaton, A.D.; Clesceri, L.S.; Greenberg, A.E. Standard methods for the examination of water and wastewater. 19.ed. Washington, DC: APHA, 1995. p.(9) 52-60

6. Flowers, R.S.; D’Aoust, J.Y.; Andrews, W.H.; Bailey, J.S. Salmonella. In: Vanderzant, C.; Spittstoesser, D.F. Compendium of methods for the microbiological examination of foods. Washington, DC: APHA, 1992, p.371-422.

7. Hitchins, A.D.; Hartman, P.A.; Todd, E.C.D. Coliforms- Escherichia coli and its toxins. In: Vanderzant, C.; Spittstoesser, D.F. Compendium of methods for the microbiological examination of foods. Washington, DC: APHA, 1992, p.325-369.

8. Kageruka, P.; Brandt, J.R.A.; Taelman, H.; Jonas, C. Modified Köster staining method for the diagnosis of cryptosporidiosis. Ann. Soc. Belge. Méd. Trop., 64: 171-175, 1984.

9. Marzochi, M.C.A. Estudo dos fatores envolvidos na disseminação dos enteroparasitas. II - Estudo da contaminação de verduras e solo de hortas na cidade de Ribeirão Preto, SP, Brasil. Rev. Inst. Med. Trop., 19(3): 148-155, 1977.

10. Marzochi, M.C.A. Poluição e enteroparasitoses. Ciência e Cultura, 29(7): 771-778, 1977.

11. Monge, R.; Chinchilla, M. Presence of Cryptosporidium oocysts in fresh vegetables. J. Food Prot., 59(2): 202-203, 1995.

12. Oliveira, C.A.F.; Germano, P.M.L. Estudo da ocorrência de enteroparasitas em hortaliças comercializadas na região metropolitana de São Paulo, SP, Brasil. I - Pesquisa de helmintos. Rev. Saúde Públ., 26(4): 283-289, 1992.

13. Oliveira, C.A.F.; Germano, P.M.L. Estudo da ocorrência de enteroparasitas em hortaliças comercializadas na região metropolitana de São Paulo, SP, Brasil. II - Pesquisa de protozoários intestinais. Rev. Saúde Públ., 26(5): 332-335, 1992.

14. Raven, P.H.; Evert, R.F.; Curtis, H. Biologia Vegetal. Guanabara Dois, Rio de Janeiro, 1978, 724p.

15. Riedel, G. Controle Sanitário dos Alimentos. Atheneu, São Paulo, 1992, 320p.

16. São Paulo. Leis, decretos, etc. Centro de Vigilância Sanitária, Portaria CVS-21 de 19/12/91. D.O.E. de 24/12/91, seção 1, p.18.

17. São Paulo. Leis, decretos, etc. Decreto $\mathrm{n}^{\circ} 12.486$ de 20 de outubro de 1978, p.178-180.

18. Silva, J.P.; Marzochi, M.C.A.; Camillo-Coura, L.; Messias, A.A.; Marques, S. Estudo da contaminação por enteroparasitas em hortaliças comercializadas nos supermercados da cidade do Rio de Janeiro. Rev. Soc. Bras. Med. Trop., 28(3): 237-241, 1995.

19. Smith, J.L. Cryptosporidium and Giardia as agents of foodborne disease. J. Food Prot., 56(5): 451-461, 1993. 